\title{
Pre-copulatory courtship behavior in a solitary bee, Nomia triangulifera Vachal (Hymenoptera: Halictidae)
}

\author{
WT Wcislo ${ }^{1, \star}$, RL Minckley 1, HC Spangler 2 \\ 1 University of Kansas, Snow Entomological Museum, Department of Entomology, \\ Lawrence, KS 66045-2119; \\ 2 USDA-ARS Carl Hayden Bee Research Center, 2000 E Allen Rd, Tucson, AZ 85719, USA
}

(Received 27 November 1991; accepted 19 May 1992)

\begin{abstract}
Summary - Complex courtship behavior occurs both before and during mating of a solitary bee, Nomia triangulifera. Males begin emerging before females, and patrol over the emergence site, although some males also fly near sunflower plants, the exclusive food source of the females. The sizes of males patrolling at these two locations, and those collected while mating were not significantly different. Courtship behavior involves use of the fore- and mid-legs, the metasoma (abdomen), antennae, and the indirect flight muscles to produce loud, audible buzzes. The hind legs have expanded tibiae which are used for clasping the female. Females rarely mated more than once when held in cages. Receptive females usually lacked sperm in their spermathecae, while unreceptive females often had sperm.
\end{abstract}

Nomia triangulifera / Halictidae / mating behavior / sexual selection

\section{INTRODUCTION}

Many features of a male's behavior and morphology are assumed to function to induce a female to initiate copulation, and then stimulate her to continue reproductive behavior (eg sperm transport, ovulation), thereby increasing the probability that the copulating male will fertilize her ova (Eberhard, 1985). Such behavior is believed to underlie the evolutionary process of sexual selection by female choice (eg Darwin, 1871; Richards, 1927; Alcock and Gwynne, 1991; West-Eberhard, 1984). Alternatively, species-specific courtship behavior functions in contexts of reproductive isolation or mate recognition (Verrell, 1988).

Most studies to date have reported little or no pre-copulatory courtship behavior among bees (eg Batra, 1966; Barrows, 1975; Alcock et al, 1978; Triplett and Gittins, 1988; Eberhard, 1991). Nomia (Epinomia) triangulifera Vachal, reported on

\footnotetext{
* Present address: WT Wcislo, Cornell University, Dept of Entomology, Ithaca, NY 14853, USA.
} 
here, seems unusual because of its extremely complex pre-copulatory courtship behavior, combined with structural modifications. The genus Nomia (Hymenoptera: Halictidae) occurs throughout most regions of the world, and in the New World is represented by 20 species in four subgenera (Moure and Hurd, 1987)*. Most male Nomia have highly modified hind legs, metasomal sterna and genitalia, which provide species-specific taxonomic characters (eg Cross, 1958; Michener, 1965; Ribble, 1965). The biological functions of these secondary sexual characters are unknown, and comparative studies of the mating biology of this group promise to illuminate their function. This report, together with previous observations on this species from another locality (Cross and Bohart, 1960), may provide an example of intraspecific divergence in courtship behavior.

\section{MATERIALS AND METHODS}

The mating behaviour of Nomia triangulifera was studied at large aggregations of nests at a farm on a floodplain along the south bank of the Kansas River between Eudora and Lawrence (Douglas County), Kansas (38 ${ }^{\circ} 57^{\prime} 30^{\prime \prime} \mathrm{N}, 95^{\circ} 7^{\prime}$ $30^{\prime \prime} W$ ). Bees have been nesting at this site at least since 1972 (Shipe, personal communication).

Courtship and mating behavior were studied by direct observation of $>200$ mating pairs. Copulating bees were largely unresponsive to nearby movements, could be approached within one $\mathrm{cm}$ (a 10X hand-lens was sometimes used), and mating pairs could even be picked up. Mating was either: i) video-taped (3.5 h) using a Panasonic videocamera with close-up lens and tripod (in 1987 and 1988); or ii) filmed (4 h) with a Paillard Bolex 16-mm film camera with an Yvar 150-mm macro-lens and tripod (in 1986).
Mating pairs were picked up and quickly placed on a platform set up in front of the camera. Approximately $7 \mathrm{~h}$ of audio recordings were made using a Uher 4000 reel-to-reel tape recorder (tape speed $=19 \mathrm{~cm} / \mathrm{s}$ ), with a standard microphone (which often served as the platform for filming). For analyses, recordings were played through a Krohn-Hite mode 3550 filter (LP $==$ $575 \mathrm{~Hz}$ ) to a Kay Elemetrics DSP Sonagraph (Model 5500).

To examine size-related patterns of mating behavior, we measured the sizes (inter-tegular distances) of females and their male partners ( $N=20$ males and 20 females), males patrolling at the emergence/nesting site $(N=44)$, and males patrolling at sunflowers $(N=51)$, using a Wild microscope with an ocular micrometer (magnification $=10 \mathrm{X})$. Some males $(N=21)$ were dried to a constant weight at $50^{\circ} \mathrm{C}$ (Thermolyne Oven-Incubator), and weighed on a Fisher electronic balance to the nearest $0.001 \mathrm{~g}$; for these males the lengths at the longest distance of the inner face of the expanded hind tibiae were also measured.

The receptivity of females in a cage was studied as follows (after O'Neill and Bjostad, 1987). After being "courted", females exhibited obvious behaviors indicating their sexual receptivity: receptive females elevated their metasoma slightly, and unreceptive females curled the metasoma under their body, and sometimes also bit at the males' legs. Receptivity status of females with otherwise unknown sexual histories was classified as follows: "receptive to 1st male and mated" (= a female copulated with the first introduced male) ( $N=34$ ); "unreceptive" (= a female refused to mate with the first male) $(N=18)$; and "receptive to 1 st male and separated before mating" (= a female was receptive to the first male, but the pair was separated before intromission) $(N=26)$. Females from these classes were individually introduced to 3-5 males in either a $16 \times 12 \times 12 \mathrm{~cm}$ net-covered fish-breeding cage, or a $1 \times 0.5 \times 1 \mathrm{~m}$ enclosure (an emergence trap) to ascertain subsequent receptivity.

Mating pairs were observed in the field, and females were categorized as "receptive but un-

\footnotetext{
* Nomia triangulifera is presently placed in the subgenus $N$ (Epinomia). In a forthcoming key, Michener et al (in preparation) recognize the genus Dieunomia for $N$ (Epinomia) and $N$ (Dieunomia), and the genus Nomia for $N$ (Acunomia) and $N$ (Curvinomia). For convenience these subgeneric names are retained in the Discussion, although it is likely that some of the groups are artificial.
} 
mated" ( $N=11$ ) (ie, males were removed before intromission), or "unreceptive" ( $N=14)$. Females were placed in vials containing insect preservative (Kahle's solution), and were later dissected and examined for presence of sperm cells in the spermathecae.

Statistical tests were from Sokal and Rohlf (1981), or calculated using Statview on a Mackintosh computer.

Voucher specimens of the bees are in the Snow Entomological Museum, and audio recordings are in the Cornell University Library of Natural Sounds; video and audio recording may be obtained from the first author.

\section{RESULTS}

$N$ triangulifera was active from mid- to lateAugust and into September in eastern Kansas. The populations were protandrous, but after several days the emergence distributions of the sexes overlapped. On all dates there was a heavily male-biased operational sex ratio, both in a year when the secondary sex ratio was near equality, and one when it was male biased (Wcislo, 1992). Males flew in great numbers over the previous year's nest site, which was where receptive females emerged and where they returned to nest if the plant cover was suitably sparse. Males were also abundant on the plant (Helianthus annuus) from which females gathered pollen and nectar; males also drank sunflower nectar. Males flying near plants frequently pounced on females, but successful copulations were never observed there. After mating, females dug nests which they provisioned with sunflower pollen and nectar. Approximately 2-3 weeks after initial emergence, males became rare at the nest site and were frequently collected on flowers, while female continued provisioning nests.

Courtship behavior of $N$ triangulifera was also briefly observed at a small aggregation near the levee north of the entrance to River Front Park, Lawrence, and at a site 5 miles north-west of Lawrence (described in Cross and Bohart, 1960). At both sites courtship behavior was qualitatively similar to behavior described below (Wcislo, unpublished observations).

Most of our observations were of mating pairs on the ground at the emergence site. We do not known the relative abundance of receptive females at the emergence sites and at flowers. Males were never observed successfully mating on flowers ( $>N=32$ attempted matings), even on plants close to the emergence site. Males flying over the emergence/nesting site were not, on average, different in size from males collected at sunflower plants nor from males collected with females in copula $(P>0.5$, with repeated Mann-Whitney $U$ tests).

The courtship behavior involved motions of the antennae, all three pairs of legs, the metasoma and associated sternal modifications, and presumably the dorsoventral flight muscles. Several details did not fully agree with the description of courtship behavior by Cross and Bohart (1960), based upon their limited observations of a Utah population; descriptions by those authors are parenthetically italicized for comparison, indicated by " $\mathrm{C}$ and B". Otherwise, descriptions given below agree with those by Cross and Bohart (1960).

In the nesting area males flew rapidly over the ground where females emerged, and frequently alighted to inspect or enter nest entrances and emergence holes. Upon contacting a female, a male rapidly climbed on her, and wrapped his hind legs around the latero-ventral portion of metasomal sterna 1-3 (C and $\mathrm{B}$ : "His hind legs lock beneath the posterior portion of her abdomen"). The hind tibiae are greatly expanded, and the inner faces are contoured to fit the general shape of the female metasoma. Males with larger inter-tegular distances had larger faces on their inner hind 
tibiae (Kendall's $t=0.52, P=0.002, N=$ 21). Throughout the courtship, but especially soon after pairing, other males flew at and pounced on the mating pair: sometimes a cluster of up to 8 males crawled over a mating pair. The expanded male tibiae prevented a male from being knocked off a female, or atherwise prevented the pair from being separated. In numerous observations ( $>200$ ), a male in copula was never displaced from a female by other males. The expanded tibia as well as the femur both have enlarged flexor muscles (Wcislo, unpublished observations).

A male's mid-legs were held lateral to the female's metasoma, nearly parallel to the longitudinal axis of her metasoma, and were directed posteriorly $(\mathrm{C}$ and $\mathrm{B}$ : " $(\mathrm{mid}$ legs are locked)... between her fore and hind wings and under her propodeum'). The male's forelegs were placed either on the pronotum, or sometimes on the front edge of the female's front wings $(C$ and $B$ : "(the male)... locks this forelegs beneath her mesothorax").

Precopulatory courtship behavior is diagrammed in figure 1. The female was nearly motionless throughout, except for occasionally grooming an antenna; sometimes a (subsequently unreceptive) female walked around the surface with a male mounted on her back. The following time durations are for $\approx 30^{\circ} \mathrm{C}$.

Both of the male's antennae were slowly moved downward in a motion lasting $1.07 \mathrm{~s}$ (SD $=0.1 ; N=9$ ), and then were rapidly flung upward $(x=0.33 \mathrm{~s}$ duration $(\mathrm{SD}=0.1 ; N=9)$ ), repeating about once per $\mathrm{S}$, giving the appearance of an asymmetric metronome ( $\mathrm{C}$ and $\mathrm{B}$ : "(there is)... alternate vertical and lateral jerking of the antennae").

The male's first pair of legs rapidly tapped the female's pronotum, quickly followed by rubbing her pleural area or mid-

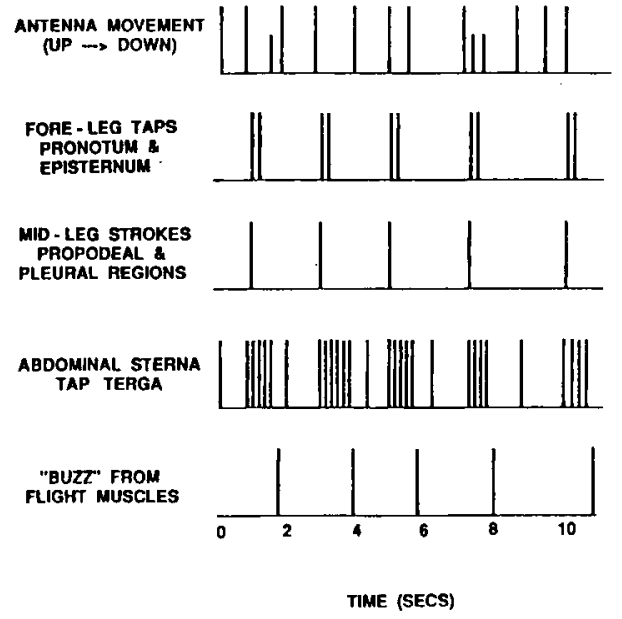

Fig 1. Representation of a portion of the precopulatory behavior of male Nomia triangulifera (Note: for the antennal motions, half bars indicate partial motions; for foreleg motions, each bar indicates that the male touches both the pronotal and pleural regions).

legs, and then repeating these movements; this entire sequence is repeated once per 1.3-2.0 s (not reported by $\mathrm{C}$ and B).

The extended mid-legs (fig 2, position A) were rotated $\approx 90^{\circ}$ around the coxae to be brought forward and downward to stroke the female's pleural region (the exact position varied with the position of the male's body) (fig 2, position B); the legs were then contracted and lifted up (fig 2, position $\mathrm{C}$ ), which again stroked the female; the legs were then counter-rotated and extended to their starting position (fig 2 , position A). After courtship has begun, the mid-legs often quivered when they were in the extended "starting" position. This sequence was repeated every 1.32.0 s (not reported by $C$ and $B$ ).

Male metasomal sternum 5 has a modified pair of protruding stubs which have a contoured and knobbed surface (there are 


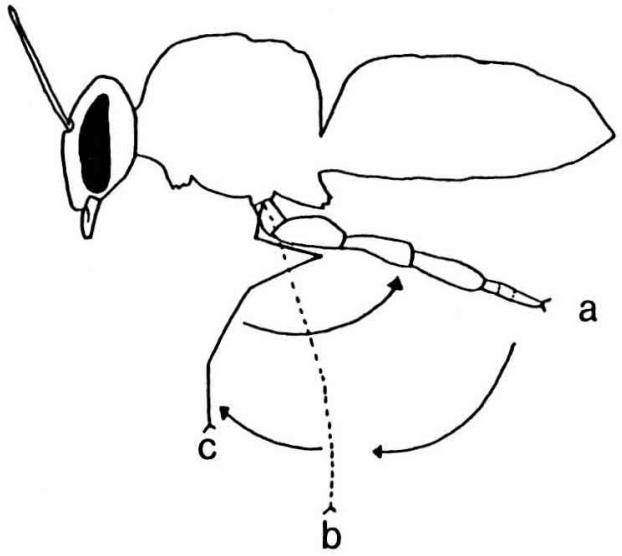

Fig 2. Schematic representation showing the motion of the male mid-leg during courtship (other legs omitted for clarity). The outlined leg (A) indicates the starting position, while the dashed and solid lines ( $B$ and $C$ ) represent intermediate positions.

species-specific modifications on this sternum in numerous species of Nomia; see refs in Introduction). A series of 4-6 taps (= one drumming bout) was delivered rapidly in succession by the male's metasoma. These taps were forceful, as evidenced by the displacement of the female's body following contact; in slow motion it is obvious that each tap did not land in the same place, and instead the male moved his metasoma to the left and to the right of center.

Following a "drumming bout", the male produced a loud "buzz" (600-900 Hz), presumably from the flight muscles (fig 3 , bottom) (not reported by $\mathrm{C}$ and $\mathrm{B}$ ); during this time the male had his mandibles open and in contact with the female's scutum or scutellum (not reported by $\mathrm{C}$ and $\mathrm{B}$ ). After these vibrations, the metasoma again tapped the female once or twice, followed by a new drumming bout. This "drumbuzz-taps" sequence was repeated up to 114 times ( $\mathrm{C}$ and $\mathrm{B}$ : the pre-copulatory mating dance lasted "several minutes"). The final sequences increased in intensity, such that drumming bouts were often accompanied by wing fluttering ( $\mathrm{C}$ and $\mathrm{B}$ : during a mating dance a male... "flutters his wings, at the same time drumming his abdomen rapidly against that of the female").

After being courted, a female indicated receptivity by slightly raising her metasoma, and the male then fluttered his wings,

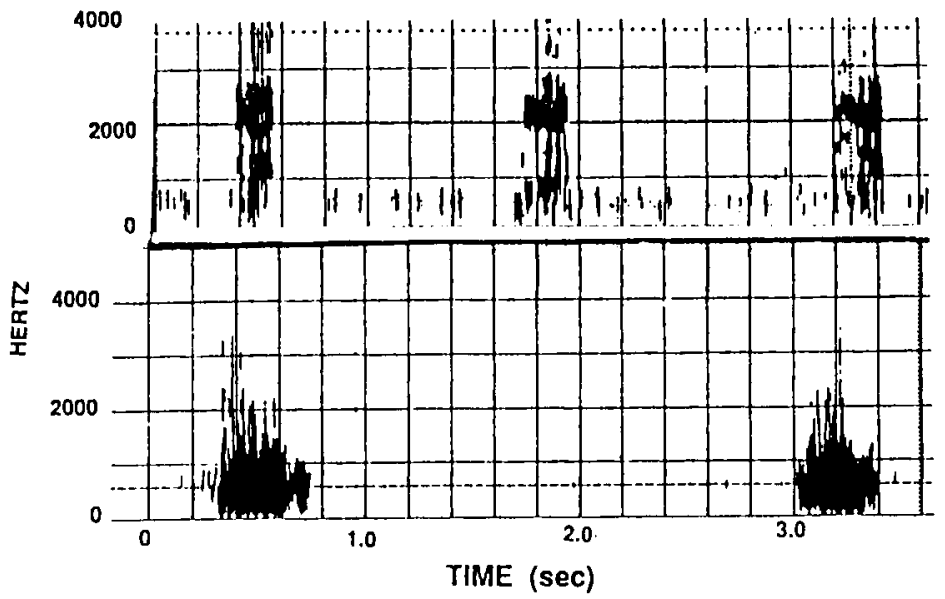

Fig 3. Bottom: representative sonagram of the pre-copulatory vibrations of male Nomia triangulifera. Top: representative sonagram of the copulatory vibrations of male Nomia triangulifera. 
and inserted an inflated membranous eversible sac (Roig, unpublished observations). During copulation the male made no other courtship motions, except for periodic contractions of the abdomen each of which occurred with a loud buzz ( $>1200$ $\mathrm{Hz}$ ) of higher frequency than the previously described buzzing that occurred before copulation (fig 3 , top) (not reported by $\mathrm{C}$ and $\mathrm{B}$; these authors reported that during copulation the male "strokes the female with his antennae at a rate of about one stroke per second"). After copulating, a male released his hind legs and then flew away. Unreceptive females, in contrast, curled their metasoma downward and forward, so that the males were unable to insert their genitalia; females often bit at the males' legs until they left.

The duration of precopulatory courtship lasted from 37-149 s $(x=70.58, S D=$ $27.47, N=55$ ), although our homosexual courtings were much briefer ( $<10 \mathrm{~s})$. The duration of actual copulation was $9.95 \mathrm{~s}$ $(\mathrm{SD}=4.32)$. For mating pairs collected at the same temperatures $\left( \pm 1^{\circ} \mathrm{C}\right)$, there was a significant positive correlation between the duration of the courtship and the duration of the copulation $(r=0.64, N=19)$. The durations of precopulatory behavior were not different for males with receptive or unreceptive females $(P>0.2$, MannWhitney $U$ test).

Females were allowed to court, or to court and mate, and then given subsequent opportunities to mate again. Table I shows that already unreceptive females, as well as recently mated ones, were not receptive to subsequent males, at least under artificial conditions. Females receptive to the first male, but not allowed to mate with him, were subsequently receptive to a second male. Such bioassays suggest that many females do not mate multiple times, although some do. Dissections of receptive and unreceptive females support this interpretation. Three of 11 pre-
Table I. The relationship between the receptivity of female Nomia triangulifera and prior sexual behavior.

\begin{tabular}{|c|c|c|}
\hline \multirow[t]{2}{*}{$\begin{array}{l}\text { Sexual experience } \\
\text { with first male }\end{array}$} & \multicolumn{2}{|c|}{$\begin{array}{r}\text { Female mates } \\
\text { with second male }\end{array}$} \\
\hline & Yes & No \\
\hline$--\cdot$ & $\cdots$ & \\
\hline Mated with 1st male & 4 & 30 \\
\hline Unreceptive to 1 st male & 3 & 15 \\
\hline $\begin{array}{l}\text { Receptive to } 1 \text { st male: } \\
\text { separated before intromission }\end{array}$ & 22 & 4 \\
\hline
\end{tabular}

viously mated females (having sperm in their spermathecae) were receptive to males, and 12 of 14 unreceptive females had sperm.

\section{DISCUSSION}

The courtship of Nomia (Epinomia) triangulifera involves extraordinarily complex mating behavior for bees (see Alcock et al, 1978; Eickwort and Ginsberg, 1980), and presumably is necessary for successful intromission. None of the unusual behaviors seen in $N(E)$ triangulifera were reported for $N(E)$ nevadensis (O'Neill and Bjostad, 1987; O'Neill, personal communication), $N$ (Acunomia) melanderi (Johansen and Mayer, 1976), or N (Curvinomia) tetrazonata tetrazonata (Wcislo, unpublished observations). Males of N (Dieunomia) heteropoda occacionally wave their antennae before intromission, and sometimes move their metasoma in a way which might suggest tapping, but might be reaching motions for the female's genital opening (Wcislo, unpublished observations). In $N(E)$ nevadensis, the initial stages of mating take place underground, if at all. "Sweetsmelling" females often emerge from the soil with males mounted on them, having 
their hind legs wrapped around the female's anterior metasoma (O'Neill and Bjostad, 1987). Intromission is accompanied by rhythmic pulsations of the male's metaso$\mathrm{ma}$, and often the female is released from the leg grasp, as is sometimes true for $N$ (D) heteropoda (Wcislo, unpublished observations). The total duration of copulation for $N(E)$ nevadensis is about twice as long as for $N(E)$ triangulifera. In $N(E)$ nevadensis mating is followed by a brief $(\approx 22 \mathrm{~s}$, on average) period when the male remains mounted on the female, but has withdrawn his aedeagus (O'Neill and Bjostad, 1987). After intromission, males of $N(E)$ triangulifera never remained with their mates.

The use of the fore- or mid-legs for stroking females is not common in the Apoidea, and to date is unknown in other Halictidae (Eberhard, 1991; Low and Wcislo,1992), including other species of Nomia. Structural modifications of male hind legs are well-known in orchid bees (Euglossinae), but they function in chemical communication, as with some male Centris bees (eg Coville et al, 1986). Expansions of the hind legs occur in many other species of Nomiinae, as well as some other Halictidae (see refs in the Introduction), Colletidae (Xeromelissinae) (Toro and Moldenke, 1979), Fideliidae (Rozen, 1970), the anthrophorid genus Ancyloscelis (Wcislo, unpublished observations) and in sphecid wasps such as Dynastus (Bohard and Menke, 1976). The hind legs of the colletids and fideliids that have been examined contain large flexor muscles and no sign of glandular material (Toro and Magunacelaya, 1987), as for several species of Nomia (Wcislo, unpublished observations). Among North American Nomia, claspers on the hind legs can be feebly developed (eg $N(E)$ boharti, or well-developed (eg $N$ (D) heteropoda)), but there is not enough information to correlate the development of such structures with allometry, or with particular mating behavior.
Several analogous elements of the courtship behavior of $N$ (E) triangulifera also occur in other Apoidea, including the Halictidae (partial review in Eberhard, 1991). Rhythmic motions of the antennae, for example, are not uncommon, as variations on a "waving", "stroking", or "tapping" theme. Danks (1971), among others, suggested that these motions function to immobilize females. The antennae of $N(E)$ triangulifera are not modified other than the usual sex differences in bees, in contrast to the broadly flattened terminal flagellomere of other nomiine bees such as $N(D)$ heteropoda or Spatunomia. In $N(C)$ tetrazonata the antennae are usually motionless before intromission, while in $N(D)$ heteropoda there is much individual variation (Wcislo, in preparation). Antennae are rhythmically moved up and down during copulation in the latter two species (Wcislo, unpublished observations) and Cross and Bohart (1960) described antennal stroking behavior for the Utah population of $N(E)$ triangulifera.

Wing vibrations or stridulations in courtship occur in some other Halictidae, and various other groups of bees (eg Rozen, 1977; Alcock and Buchmann, 1985; Larsen et al, 1986; Tengö et al, 1988; Wcislo, unpublished observations) as well as other Hymenoptera (eg Markl, 1977; Sivinski and Webb, 1989). In $N$ (E) triangulifera these pre-copulatory vibrations are at a frequency of $\approx 600 \mathrm{~Hz}$.

Curiously, a similar frequency artificially applied to honey bee (Apis) combs induces workers nearby to become akinetic (Spangler, 1969 and refs therein). Male $N(D)$ heteropoda, produce very low frequency vibrations before copulating, yet provide no further stimulation. Different frequencies may simply be related to body size (Spangler and Buchmann, 1991).

The rapid metasomal drumming was always performed by male $N(E)$ triangulife- 
ra, but its function is unknown. Abdominal musculature and morphology of the sternal glands of male $N(A)$ melanderi have been studied by Youssef (1969). Females of some species ( $N$ triangulifera and $N$ heteropoda) employ such tapping behavior to collect pollen from the open heads of sunflower with their metasomal sterna (Wcislo, unpublished observations). The use of the metasoma by males during courtship to tap or rub the female metasoma occurs sporadically in some aculeates (eg Cowan, 1986; Wcislo et al, 1988). It also sometimes occurs after copulation in Triepeolus (Wcislo, unpublished observations), and in Centris pallida such post-copulatory behavior reduces females' receptivity to remating (Alcock and Buchmann, 1985). Drumming behavior during courtship occurs independently in other orders of insects (eg Plecoptera).

The differences between the behavior of the Kansas bees reported here and those of an Utah population (Cross and Bohart, 1960) are especially striking. If substantiated, they then represent a documented case of intra-specific divergence in copulatory courtship behavior in insects (Eberhard, 1991). Cross and Bohart did not deposit voucher specimens, but Cross (1958), who most recently revised the subgenus $N$ (Epinomia), has no doubt that the species determination is correct (Cross, personal communication). Furthermore, specimens from the Utah locality in the Snow Entomological Museum, University of Kansas, are not obviously different from other $N(E)$ triangulife$r a$. The movements of the legs and antennae are very noticeable, as are the precopulatory buzzes, which are audible from up to $1 \mathrm{~m}$. It is, therefore, highly probable that Cross and Bohart would have noticed and reported such unusual behavior for bees, especially since they described the positions of the legs, antennae, etc.

If supported, these intra-specific behavioral differences may support recent ideas that sexual selection leads to rapid character evolution (refs in Introduction). At present, however, there are insufficient data to determine the evolutionary context of such elaborate courtship behavior (eg species recognition or sexual selection see discussion in Verrell, 1988). Interpopulational differences in courtship behavior have been rarely documented among insects (eg Carson and Bryant, 1979; Spiess and Carson, 1981; Bieman, 1986). Further comparative studies are needed to substantiate intra-specific differences in the courtship behavior of $N(E)$ triangulifera. More detailed studies are also needed within populations because results only report information collected when temperatures were hot $\left(>30^{\circ}\right)$ and relative humidity high. These are the usual weather conditions in Kansas in August; occasionally there are cool, wet years, but no samples have been analyzed. Larsson $(1989 a, b)$ has shown that microclimate differentially influences the reproductive success of small and large individuals of Colletes (Colletidae).

\section{ACKNOWLEDGMENTS}

We thank $G$ Shipe and $H$ Nice for their very generous hospitality and tolerance in allowing us to work on land they managed and farmed. For the use of equipment, discussions, and criticisms of the manuscript we thank $R$ Jander, $W$ Bell, and especially $C$ Michener; for additional criticisms of the manuscript we thank J Alcock, B Alexander, S Buchmann, D Conlon, E Cross, and W Eberhard. For financial support WTW gratefully acknowledges the assistance of the National Science Foundation Doctoral Dissertation Improvement Grant BNS 87-01046. This is contribution No 3062 from the Department of Entomology, University of Kansas.

Résumé - Comportement de cour précopulatoire chez une abeille solitaire, Nomia triangulifera Vachal (Hymenopte- 
ra, Halictidae). L'abeille terricole, Nomia triangulifera, présente un comportement de cour complexe avant et pendant l'accouplement. Le comportement d'accouplement a été étudié sur de grosses aggrégations dans une ferme du Nord-Est du Kansas, où les abeilles nidifient depuis de nombreuses années. En 1989 et 1990, on a capturé des abeilles qui émergeaient afin de déterminer la phénologie de l'émergence et d'estimer le sex-ratio journalier d'accouplement (nombre de mâles présents / nombre de femelles réceptives). La population est protandre (les mâles apparaîssent en premier) et le sex-ratio est toujours très en faveur des mâles (fig 1). Ceux-ci sont légèrement plus petits que les femelles et ils patrouillent en grand nombre audessus des endroits où les femelles émergent et autour des plantes où elles récoltent du pollen (Helianthus annuus, tournesol). La taille (distance intertégulaire) des mâles qui patrouillent dans ces endroits et de ceux récoltés pendant qu'ils s'accouplaient n'était pas significativement différente. Au champ, les accouplements ont été filmés avec une caméra Bolex $16 \mathrm{~mm}$ $(4 \mathrm{~h})$, enregistrès sur bande vidéo avec une caméra Panasonic ( $3,5 \mathrm{~h})$ et des enregistrements sonores ont été faits avec un microphone standard et un magnétophone Uher (7 h). L'analyse de l'ensemble de ces enregistrements montre un comportement de cour extraordinairement complexe pour une abeille. Pendant la cour, le mâle utilise ses pattes antérieures pour tapoter le pronotum de la femelle (fig 1); les pattes médianes caressent la région pleurale de la femelle (fig 2); son metasoma (abdomen) frappe rapidement celui de la femelle; ses antennes oscillent rythmiquement de haut en bas; les muscles du vol produisent un fort bourdonnement audible d'environ 600 $\mathrm{Hz}$ de fréquence (fig 3 ). Les pattes postérieures sont étendues et leur tibia est utilisé pour saisir la femelle. Pendant l'accouplement, le mâle produit une série de bourdonnements de fréquence plus élevée (environ $1200 \mathrm{~Hz}$ ), qui coïncident avec les contractions de son metasoma (fig 3). Des femelles maintenues en cage se sont rarement accouplées plus d'une fois (tableau 1). Les femelles réceptives n'avaient généralement pas de sperme dans leur spermathèque, contrairement aux femelles non réceptives qui, elles, en avaient. La comparaison du comportement des mâles de la population du Kansas avec des observations faites précédemment sur une population de l'Utah montre des différences intraspécifiques frappantes dans le comportement de cour de $N$ triangulifera. Si ces résultats sont confirmés lors de nouvelles études, ils constituent le premier cas établi de divergence intraspécifique du comportement d'accouplement chez les insectes.

\section{Nomia triangulifera / Halictidae / com- portement d'accouplement / sélection sexuelle}

\section{Zusammenfassung - Balzverhalten vor der Kopula bei einer solitären Biene, Nomia triangulifera Vachal (Hymenopt- era: Halictidae). Vor und während der Paa- rung einer solitären, bodennistenden Fur- chenbiene, Nomia triangulifera, erfolgt ein komplexes Balzverhalten. Das Paarungs- verhalten wurde an großen Ansammlungen auf einer Farm im Nordosten von Kansas studiert, wo die Bienen schon seit vielen Jahren nisten. Die Populationen sind pro- tandrisch (das heißt die Männchen erschei- nen zuerst) und das Geschlechtsverhältnis während der Paarung ist immer sehr stark zugunsten der Männchen verschoben. Die Männchen sind etwas kleiner als die Weib- chen, und sie patrollieren in großer Zahl über der Ansammlung, wo die Weibchen schlüpfen und rund um die Pflanzen (Heli- anthus annuus, Sonnenblume), wo diese Pollen sammeln. Die Größe (interteguläre}


Distanz) der Männchen, die an diesen beiden Örten patrollierten, war von derjenigen der bei der Paarung gefangenen Männchen nicht signifikant verschieden. Während der Paarung wurden die Bienen im Feld mit einer Bolex 16 mm Kamera gefilmt (4 Stunden), auf Videoband mit einer Pansonic Videokamera aufgenommen (3,5 Stunden) und die dabei hörbaren Geräusche mittels Standardmikrophon und einem Uher Tonbandgerät registriert.

Die Analysen dieser Filme und Bänder ergaben ein für eine Biene äußerst komplexes Balzverhalten. Wie in Abbildung 1 zusammengefaßt, klopft das Männchen während des Balzens mit den Vorderbeinen auf das Pronotum des Weibchens; die Mittelbeine des Männchens streichen über die Pleuralregion des Weibchens, (Abbildung 2); sein Metasoma (Abdomen) trommelt oder klopft rasch auf ihr Abdomen; seine Antennen schwingen rhythmisch auf- und abwärts; und seine Flugmuskeln erzeugen laute, hörbare Tonstöße mit einer Frequenz von ungefähr $600 \mathrm{~Hz}$ (Abbildung 3). Die Hinterbeine haben verbreiterte Tibien, die zum Ergreifen des Weibchens benutzt werden. Während der Paarung erzeugt das Männchen eine Serie von Tonstößen höherer Frequenz (bis $1200 \mathrm{~Hz}$ ), gleichzeitig mit Kontraktionen seines Metasomas (Abbildung 3). Bei Käfighaltung paarten sich Weibchen nur selten mehr als einmal (Tabelle I). Paarungsbereite Weibchen hatten nur selten Samen in ihrer Spermatheka, während bei paarungsunwilligen Weibchen gewöhnlich Samen gefunden wurden.

Vergleiche des Verhaltens der Männchen in der Population von $N$ triangulifera von Kansas mit früheren Beobachtungen an einer Population derselben Art in Utah zeigen Unterschiede im Balzverhalten innerhalb der Art.

Wenn diese. Befunde durch noch eingehendere Studien bestätigt werden können, so ist dies der erste dokumentier- te Fall von Unterschieden im Paarungsverhalten innerhalb ein und derselben Art bei Insekten.

\section{Nomia triangulifera / Halictidae / Paa- rungsverhalten / Sexuelle Selektion}

\section{REFERENCES}

Alcock J, Buchmann SL (1985) The significance of post-insemination display by male Centris pallida (Hymenoptera: Anthophoridae). $Z$ Tierpsychol 68, 231-243

Alcock J, Gwynne DT (1991) Evolution of insect mating systems: the impact of selectionist thinking. In: Reproductive Behaviour of $/ n$ sects: Individuals and Populations (Bailey WJ, Ridsdill-Smith J, eds) Chapman, London

Alcock J, Barrows EM, Gordh G, Hubbard LJ, Kirkendall LL, Pyle D, Ponder TL, Zalom FG (1978) The ecology and evolution of male reproductive behaviour in the bees and wasps. Zool J Linn Soc 64, 293-326

Barrows EM (1975) Mating behavior in halictine bees (Hymenoptera: Halictidae): III. Copulatory behavior and olfactory communication. Insectes Soc 22, 307-322

Batra SWT (1966) The life cycle and behavior of the primitively social bee, Lasioglossum zephyrum (Halictidae). Univ Kansas Sci Bull 64, 359-423

Bieman CFM den (1986) Acoustic differentiation and variation in planthoppers of the genus $R i$ bautodelphax (Homoptera, Delphacidae). Netherlands J Zool 36, 461-480

Bohart RM, Menke AS (1976) Sphecid Wasps of the World. University of California Press, Berkeley, CA

Carson HL, Bryant PJ (1979) Change in a secondary sexual character as evidence of incipient speciation in Drosophila silvestris. Proc Natl Acad Sci USA 76, 1929-1932

Coville RE, Frankie GW, Buchmann SL, Vinson SB, Williams HJ (1986) Nesting and male behavior of Centris heithausi (Hymenoptera: Anthophoridae) in Costa Rica with chemical analysis of the hindleg glands of males. $J$ Kansas Entomol Soc 59, 325-336

Cowan DP (1986) Sexual behavior of eumenid wasps. Proc Entomol Soc (Wash) 88, 531-541 
Cross EA (1958) A revision of the bees of the subgenus Epinomia in the New World $(\mathrm{Hy}$ menoptera: Halictidae). Univ Kansas Sci Bull 38, 1261-1301

Cross EA, Bohart GC (1960) The biology of Nomia (Epinomia) triangulifera with comparative notes on other species of Nomia. Univ Kansas Sci Bull 41, 761-792

Danks HV (1971) Biology of some stem-nesting aculeate Hymenoptera. Trans $R$ Entomol Soc (Lond) 122, 323-399

Darwin C (1871) The Descent of Man and Selection in Relation to Sex (1986 reprint). Princeton University Press, Princeton

Eberhard WG (1985) Sexual Selection and Animal Genitalia. Harvard University Press, Cambridge

Eberhard WG (1991) Copulatory courtship and cryptic female choice in insects. Biol Rev 66 , 1-31

Eickwort GC, Ginsberg HS (1980) Foraging and mating behavior in Apoidea. Annu Rev Ento$\mathrm{mol} 25,421-446$

Johansen C, Mayer D (1976) Alkali bees: their biology and management for alfalfa seed production in the Pacific Northwest. Pac Northwest Ext Pub/ 155, 1-19

Larsen O, Gleffe G, Tengö J (1986) Vibration and sound communication in solitatory bees and wasps. Physiol Entomol 11, 287-296

Larsson $F(1989 a)$ Insect mating patterns explained by microclimatic variables. $J$ Therm Biol 14, 155-157

Larsson $F(1989 b)$ Mating patterns in six insect species: effects of weather and population density. Acta Univ Ups Abstr Upps Dis Sci 234, 1-31

Low BS, Wcislo WT (1992) Foretibial plates and the mating behavior of Crabo cribrellifer $(\mathrm{Hy}$ menoptera: Sphecidae), with a review of male foreleg modifications in Apoidea. Ann Entomol Soc Am

Markl H (1977) Mating behavior and sound production in harvester ants (Pogonomyrmex, Formicidae). Insectes Soc 24, 191-212

Michener CD (1965) A classification of the bees of the Australian and South Pacific regions. Bull Am Mus Nat Hist 130, 1-362

Moure JS CMF, Hurd PD Jr (1987) An Annotated Catalog of the Halictid Bees of the Western Hemisphere (Hymenoptera: Halictidae).
Smithsonian Institution Press, Washington, DC

O'Neill KM, Bjostad L. (1987) The male mating strategy of the bee Nomia nevadensis (Hymenoptera: Halictidae): leg structure and mate guarding. Pan-Pac Entomol 63, 207. 217

Ribble DW (1965) A revision of the banded subgenera of Nomia in America (Hymenoptera: Halictidae). Univ Kansas Sci Bull 45, 277358

Richards OW (1927) Sexual selection and allied problems in insects. Biol Rev 2, 298-360

Rozen JG Jr (1970) Biology, immature stages, and phylogenic relationships of fideliine bees, with the description of a new species of $\mathrm{NeO}$ fidelia (Hymenoptera, Apoidea). Am Mus Novit 2427, 1-25

Rozen JG Jr (1977) Biology and immature stages of the bee genus Meganomia (Hymenoptera, Melittidae). Am Mus Novit 2630, 1-14

Sivinski J, Webb JC (1989) Acoustic signals produced during courtship in Diachasmimorpha (=Biosters) longicaudata (Hymenoptera: Braconidae) and other Braconidae. Ann Entomol Soc Am 82, 116-120

Sokal RR, Rohlf FJ (1981) Biometry. WH Freeman and Co, New York, NY, 2nd edn

Spangler HG (1969) Suppression of honey bee flight activity with substrate vibration. $J$ Econ Entomol 62, 1185-1186

Spangler HG, Buchmann SL (1991) Effects of temperature on wingbeat frequency in solitary bee Centris caesalpinae (Anthophoridae: Hymenoptera). J Kansas Entomol Soc 64, 107-109

Spiess EB, Carson HL (1981) Sexual selection in Drosophila silvestris of Hawaii. Proc Natt Acad Sci USA 78, 3088-3092

Tengö J, Eriksson J, Borg-Karlson AK, Smith $\mathrm{BH}$, Dobson H (1988) Mate-locating strategies and multimodal communication in male mating behavior of Panurgus banksianus and $P$ calceratus (Apoidea, Andrenidae). J Kansas Entomol Soc 61, 388-395

Toro H, Moldenke A (1979) Revision de los Xeromellisinae chileños (Hymenoptera, Colletidae). Ann Mus Hist Nat Valp 12, 95-182

Toro H, Magunacelaya JC (1987) Estructura muscular femoral de Xeromelissinae (Hymenoptera: Colletidae). Acta Entomol Chil 14, 13-24 
Triplett DC, Gittins AR (1988) Nesting, mating and foraging habits of Melissodes (Melissodes) tepida tepida Cresson in Idaho (Hymenoptera: Anthophoridae). Proc Entomol Soc (Wash) 90, 462-470

Verrell PA (1988) Stabilizing selection, sexual selection and speciation: a view of specific-mate recognition systems. Syst Zool 37, 209-215

Wcislo WT (1992) Attraction and learning in the mate-finding behavior of solitary bees, Lasioglossum (Dialictus) figueresi Wcislo and Nomia triangulifera Vachal (Hymenoptera: Halictidae). Behav Ecol Sociobiol 31, 139-148

Wcislo WT, West-Eberhard MJ, Eberhard WG (1988) Natural history and behavior of a primi- tively social wasp, Auplopus semialatus, and its parasite, Irenangelus eberhardi (Hymenoptera: Pompilidae). J Insect Behav 1, 247-260

West-Eberhard MJ (1984) Sexual selection, competitive communication, and speciesspecific signals in insects. In: Insect Communication (Lewis TN, ed) Academic Press, New York, NY

West-Eberhard MJ (1991) Sexual selection and social behavior. In: Man and Beast Revisited (Tiger L, Robinson MH, eds) Smithsonian Institution Press, Washington, DC

Yousseff NN (1969) Musculature, nervous system and glands of metasomal abdominal segments of the male of Nomia melanderi Ckll (Hymenoptera, Apoidea). J Morphol 129, 59-80 